\section{Improving Cut Flower Production of Balloon Flower}

\author{
Abraham H. Halevy ${ }^{1}$, Eitan Shlomo, and Ofra Ziv \\ Department of Horticulture, The Hebrew University of Jerusalem, P.O. Box \\ 12, Rehovot 76100, Israel
}

Additional index words. growing temperatures, gibberellin, photoperiod, precooling, Platycodon grandiflorus

\begin{abstract}
Experiments aiming to adapt the perennial balloon flower (Platycodon grandiflorus) as a commercial cut flower crop were conducted for 4 years under various growing conditions: four controlled-temperature rooms at two photoperiods in a phytotron, heated and unheated greenhouses, and a saran net-house (15\% shade). Best flower yield was obtained following crown cooling for 12 weeks at 2 to $4{ }^{\circ} \mathrm{C}$. Platycodon is a day-neutral plant, but produce more flowering stems under long days. Flower initiation and development is enhanced with increased growing temperature from $17 / 12{ }^{\circ} \mathrm{C}$ (day/night) to $27 / 22{ }^{\circ} \mathrm{C}$. At very high temperatures $\left(32 / 24{ }^{\circ} \mathrm{C}\right)$, however, only a few flowers are formed. Best quality stems were produced at 12 to $14{ }^{\circ} \mathrm{C}$ night temperature. At higher night temperatures, flowering stems were thin and weak. Gibberellin treatments to the crowns and the plants did not affect flowering time. Chemical name used: gibberellin $\left(\mathrm{GA}_{3}\right)$.
\end{abstract}

The common name of Platycodon grandiflorus A. DC. is balloon flower, since in unopened flowers, the petals remain fused, and the inflated buds resemble small balloons. Platycodon, a native to northeast Asia (China, Manchuria, and Japan), belongs to the Campanulaceae, and is the only species in this genus (Armitage, 1989; Bailey, 1935; Everett, 1981).

Platycodon is a hardy herbaceous perennial plant that is normally propagated from seeds. At the end of the growing season, it forms a carrot-like storage root with renewal buds at its top ("crown"). The above-ground parts of the plant die in the late autumn and it becomes dormant. It requires a certain cold period to break dormancy, and promotes sprouting and flowering (Iversen and Weiler, 1994).

Platycodon was grown mainly as a garden and bedding plant until recently when pot and cut-flower cultivars were introduced. The most common flower color is blue, but there are also white and light-pink cultivars. Park et al. (1998) and Song et al. (1993) studied the effect of light conditions and growing temperatures on seedlings.

Brief reports were published on the plant's response to photoperiod and crown cooling (Iversen and Weiler, 1994), and on the postharvest treatment of flowers (Eversen and Beattie, 1986). There are no detailed studies on the flowering requirements of balloon flower, grown for several flushes under mild winter conditions. This study presents the results of experiments conducted over 4 years

\footnotetext{
Received for publication 18 Jan. 2001. Accepted for publication 15 Oct. 2001. This research was supported by the Pearlstein Family Fund for Research in ornamental horticulture at the Hebrew Univ. We thank the donors for their support.

${ }^{1}$ To whom reprint requests should be addressed. Fax:+972-8-9468263; E-mail address: ahalevy@ agri.huji.ac.il
}

under various growing conditions: controlled temperature and photoperiods in a phytotron, heated and unheated greenhouses and saran net-houses. The purpose of these studies was to evaluate how temperature and light conditions affect growth and flowering of balloon flower for commercial cut flower production.

\section{Materials and Methods}

Experiments were conducted with balloon flower 'Fuji Blue' (Sakata Seed Co., Yokohama, Japan). The initial propagation was from seeds, but later most of the experiments were conducted with plants originated from crowns obtained from seeded plants. In most trials (unless otherwise stated), the crowns were cooled for 12 weeks at 2 to $4{ }^{\circ} \mathrm{C}$ before planting, following results of preliminary experiments (Shlomo et al., 2000). During storage or cooling, crowns were packed in wet

Experiments were conducted under various growth conditions at the Hebrew Univ. facilities in Rehovot, Israel: fully temperature- and photoperiod-controlled conditions in the phytotron, heated and unheated greenhouses, and a saran net-house. In the phytotron, the plants were grown individually in 20 -cm clay pots in a medium consisting of 1 finish peat : 1 volcanic gravel (scoria) : 1 granulated polystyrene foam (by volume). There were four temperature rooms, with $5^{\circ} \mathrm{C}$ difference between day and night temperatures: $17 / 12,22 / 17,27 / 22$, and $32 / 27^{\circ} \mathrm{C}$ (day/ night). Two photoperiods were used: short day (SD) $-8 \mathrm{~h}$ natural day light, and long day (LD) $-8 \mathrm{~h}$ natural daylight plus $8 \mathrm{~h}$ with incandescent light of $3.5 \mu \mathrm{mol} \cdot \mathrm{m}^{-2} \cdot \mathrm{s}^{-1}$. Plants were irrigated twice daily, once with halfstrength Hoagland solution and once with water. Five to seven replications were used for each treatment in the phytotron experiments. vermiculite.
Each experiment was repeated twice with similar results. Results of one experiment are presented.

In the greenhouses and net-houses, the plants were grown in ground beds of sandy loam soil. Drip irrigation was used for fertigation according to common practices. The unheated greenhouse was a polyhouse with temperatures varying from 8 to $14{ }^{\circ} \mathrm{C}$ at night to 12 to $30^{\circ} \mathrm{C}$ during the day. The heated greenhouse was a glasshouse with night temperature at $16^{\circ} \mathrm{C}$ and day temperatures varied from 16 to $28{ }^{\circ} \mathrm{C}$. The saran net-house was covered with net that caused $10 \%$ to $15 \%$ reduction in solar radiation. The plants were exposed to ambient changes in temperatures that varied from $8{ }^{\circ} \mathrm{C}$ (night) to $30{ }^{\circ} \mathrm{C}$ (day). Maximum daily photosynthetic photon flux $(P P F)$ radiation varied from 600 to 1600 $\mu \mathrm{mol} \cdot \mathrm{m}^{-2} \cdot \mathrm{s}^{-1}$ and solar radiation [photosynthetically active radiation $(P A R)]$ varied from 22 to $38 \mathrm{~mol} \cdot \mathrm{m}^{2} \cdot \mathrm{d}^{-1}$. The experiments conducted in the greenhouses and net-houses were arranged in randomized blocks using 20 plants per treatment ( 4 blocks $\times 5$ plants).

Influence of crown splitting and cooling on flowering of four growth flushes. Three-yearold crowns weighing 290 to 360 g were divided into four lots. Two remained intact and two were split into two to four units weighing 90 to $130 \mathrm{~g}$. Half of the crowns in each group were cooled for 12 weeks at $2{ }^{\circ} \mathrm{C}$ before planting and the other half remained in an uncontrolled room conditions ( 18 to $27^{\circ} \mathrm{C}$ ). All of the crowns were planted on 29 Oct. in ground beds of an unheated greenhouse, under ambient temperature and light conditions. Planting density was 12 per $\mathrm{m}^{2}$ for the intact crowns and 25 per $\mathrm{m}^{2}$ for the divided crowns. The plants grew in the greenhouse for four growth flushes. After each flush, the plants were pruned to their bases and the beds were mulched with 6-cm-height perlite to avoid over heating of the crowns. Irrigation was stopped a week before pruning and rewatering started a week after pruning. The experiment was terminated after four flowering flushes.

Comparison of plants grown from seeds to those grown from crowns. Three-week-old plants grown from seeds or from 2-year-old crowns precooled for 12 weeks at $2{ }^{\circ} \mathrm{C}$ were planted in pots and grown in a saran net-house for 1 month. They were then transferred to the phytotron in a $27 / 22^{\circ} \mathrm{C}$ room under two photoperiods.

Effect of daylength and growing temperatures on flowering. Bare-root crowns cooled for 12 weeks were planted in pots. They were held in the net-house for 3 weeks and then transferred to the growth rooms in the phytotron, under various temperature and daylength conditions.

Comparison of winter growth in a heated and an unheated greenhouse. Two-year-old cooled crowns were planted on 1 Oct. in sandy loam soil beds either in a greenhouse heated to minimum of $16{ }^{\circ} \mathrm{C}$ or in an unheated greenhouse with night temperatures ranging from 8 to $14{ }^{\circ} \mathrm{C}$. Average daily temperature was $22.3^{\circ} \mathrm{C}$ in the heated greenhouse and $19.8^{\circ} \mathrm{C}$ in the unheated one. Plants were grown under 
these conditions for two growth flushes. At the end of the first flowering flush, the plants were pruned down to their bases and mulched as in Expt. 1.

Effect of cooling temperature, length of cooling and $\mathrm{GA}_{3}$ treatments on flowering. To mimic winter conditions in the regions of native Platycodon plants (north China and Manchuria), 2-year-old crowns were cooled for 10 weeks at $-2{ }^{\circ} \mathrm{C}, 2{ }^{\circ} \mathrm{C}$, and $4{ }^{\circ} \mathrm{C}$. They were then planted on two dates, 5 Sept. and 1 Oct., in two greenhouses, one heated and one unheated.

In another trial, the optimal length of cold storage of crowns was tested. Two-year-old plants were grown during the winter and early summer in an unheated greenhouse. They were mulched after pruning as in Expt. 1. The crowns were dug at various times in the summer and transferred to a cold room at $2{ }^{\circ} \mathrm{C}$, for various lengths of time. All crowns were planted on 1 Oct.

To test if $\mathrm{GA}_{3}$ can replace or reduce the cooling requirement of balloon flower, five crowns from each cooling treatment were dipped in $\mathrm{GA}_{3}$ solutions of 100 and $250 \mathrm{ppm}$ for 10 or $20 \mathrm{~min}$ before planting. In other trials, plants were sprayed one to three times with 100 to 500 ppm $\mathrm{GA}_{3}$.

\section{Results and Discussion}

Influence of crown splitting and cooling on flowering. The first flowering flush began 2 months after planting on 1 Jan. and ended on 5 Feb. Average daily temperature (ADT) during this flush was $17.3^{\circ} \mathrm{C}$ and average light integral $26 \mathrm{~mol} \cdot \mathrm{m}^{2} \cdot \mathrm{d}^{-1}$. Crown cooling greatly increased flower production and quality (Table 1). The flowering stems were longer and bore more flower buds per stem. The divided crowns produced fewer flowers than intact crowns. ADT at the second flush was $26.2{ }^{\circ} \mathrm{C}$ and average light integral was $29 \mathrm{~mol} \cdot \mathrm{m}^{2} \cdot \mathrm{d}^{-1}$. Flowering of this flush began on 1 May and ended on 15 May. In this flush, cooled crowns also produced more flowering stems and the stems from the cooled crowns were longer. The difference between the intact and divided crowns was, however, small and insignificant in the second flush. Flowering in the third flush began on 27 July and lasted for 2 weeks. ADT during this flush was $28.4{ }^{\circ} \mathrm{C}$ and average light integral was $34 \mathrm{~mol} \cdot \mathrm{m}^{2} \cdot \mathrm{d}^{-1}$. The advantage of the cooled crowns in flowering stem production was obvious also in this flush. The flowering stems in this flush were, however, shorter. ADT during the fourth flush was $28.2{ }^{\circ} \mathrm{C}$ and average light integral 33 $\mathrm{mol} \cdot \mathrm{m}^{2} \cdot \mathrm{d}^{-1}$. Flowering of the fourth flush started on 13 Oct. The number of flowers produced and their quality were lower than in the previous flushes (Table 1).

Comparison of plant grown from seeds to those grown from crowns. Daylength did not affect flowering time, but there was a considerable increase in flower production under LD (Table 2). The type of plant did not affect the time of flowering. However, there was more flowering shoots and longer stems in plants grown from crowns.

Table 1. Effect of cooling and splitting of crowns of Platycodon on four flowering flushes in an unheated greenhouse.

\begin{tabular}{|c|c|c|c|c|}
\hline \multicolumn{2}{|c|}{ Treatment } & \multirow{2}{*}{$\begin{array}{c}\text { Length of } \\
\text { flowering stems } \\
(\mathrm{cm}) \\
\end{array}$} & \multirow{2}{*}{$\begin{array}{c}\text { No. of } \\
\text { flowering stems } \\
\text { per plant }\end{array}$} & \multirow{2}{*}{$\begin{array}{c}\text { No. of } \\
\text { flower buds } \\
\text { per stem } \\
\end{array}$} \\
\hline Cooled & Split & & & \\
\hline \multicolumn{5}{|c|}{ First flush } \\
\hline - & + & $53.2 \mathrm{c}^{\mathrm{x}}$ & $1.6 \mathrm{~d}$ & $6.3 \mathrm{c}$ \\
\hline+ & + & $74.6 \mathrm{~b}$ & $6.0 \mathrm{~b}$ & $9.8 \mathrm{~b}$ \\
\hline - & - & $52.8 \mathrm{c}$ & $4.2 \mathrm{c}$ & $5.2 \mathrm{c}$ \\
\hline+ & - & $82.0 \mathrm{a}$ & $11.7 \mathrm{a}$ & $7.2 \mathrm{c}$ \\
\hline \multicolumn{5}{|c|}{ Second flush } \\
\hline - & + & $61.3 \mathrm{~b}$ & $1.8 \mathrm{~d}$ & $16.3 \mathrm{a}$ \\
\hline+ & + & $76.1 \mathrm{~b}$ & $4.7 \mathrm{e}$ & $12.4 \mathrm{ab}$ \\
\hline - & - & $64.5 \mathrm{~b}$ & $2.2 \mathrm{~d}$ & $19.2 \mathrm{a}$ \\
\hline+ & - & $82.2 \mathrm{a}$ & $5.7 \mathrm{~b}$ & $18.6 \mathrm{a}$ \\
\hline \multicolumn{5}{|c|}{ Third flush } \\
\hline - & + & $46.5 \mathrm{~cd}$ & $3.3 \mathrm{~cd}$ & $6.4 \mathrm{c}$ \\
\hline+ & + & $54.6 \mathrm{c}$ & $10.9 \mathrm{a}$ & $16.3 \mathrm{ab}$ \\
\hline - & - & $48.4 \mathrm{c}$ & $7.3 \mathrm{~b}$ & $12.4 \mathrm{ab}$ \\
\hline+ & - & $49.8 \mathrm{c}$ & $13.2 \mathrm{a}$ & $18.1 \mathrm{a}$ \\
\hline \multicolumn{5}{|c|}{ Fourth flush } \\
\hline - & + & $41.2 \mathrm{~d}$ & $2.0 \mathrm{~d}$ & $4.3 \mathrm{~cd}$ \\
\hline+ & + & $43.3 \mathrm{~d}$ & $4.3 \mathrm{c}$ & $6.2 \mathrm{c}$ \\
\hline - & - & $44.2 \mathrm{~d}$ & $3.4 \mathrm{~cd}$ & $6.8 \mathrm{c}$ \\
\hline+ & - & $45.4 \mathrm{~cd}$ & $4.6 \mathrm{c}$ & $7.2 \mathrm{c}$ \\
\hline
\end{tabular}

${ }^{2}$ Only flowering stems of exportable quality (strong stems, $50 \mathrm{~cm}$ and longer). y Open flowers and buds showing color.

xMean separation within columns by Duncan's multiple range test, $P \leq 0.05$. Means of 20 plants ( 4 blocks $\times 5$ plants).

Table 2. Effect of daylength and growth at $27 / 22{ }^{\circ} \mathrm{C}$ in the phytotron on flowering of plants originated from seeds or 2 year old crowns. SD was of $8 \mathrm{~h}$ natural day light and LD of $8 \mathrm{~h}$ natural day light plus $8 \mathrm{~h}$ of incandescent light of $3.5 \mu \mathrm{mol} \cdot \mathrm{m}^{-2} \cdot \mathrm{s}^{-1}$.

\begin{tabular}{|c|c|c|c|c|c|c|}
\hline \multirow{2}{*}{$\begin{array}{l}\text { Origin } \\
\text { plants } \\
(\mathrm{cm})\end{array}$} & \multicolumn{2}{|c|}{$\begin{array}{c}\text { Days to first } \\
\text { flowering } \\
\end{array}$} & \multicolumn{2}{|c|}{$\begin{array}{c}\text { No. of flowering } \\
\text { stems per plant }\end{array}$} & \multicolumn{2}{|c|}{$\begin{array}{l}\text { Length of flowering } \\
\text { stems }(\mathrm{cm})\end{array}$} \\
\hline & LD & SD & LD & $\overline{S D}$ & LD & SD \\
\hline Seed & $37 \mathrm{a}^{\mathrm{z}}$ & $39 a$ & $7.7 \mathrm{~b}$ & $1.5 \mathrm{c}$ & $37.5 \mathrm{~b}$ & $36.2 \mathrm{~b}$ \\
\hline Crown & $39 \mathrm{a}$ & $39 a$ & $11.6 \mathrm{a}$ & $6.5 \mathrm{~b}$ & $54.3 \mathrm{a}$ & $49.0 \mathrm{a}$ \\
\hline
\end{tabular}

${ }^{2}$ Mean separation within columns by Duncan's multiple range test, $P \leq 0.05$. Means of 6 plants.

Table 3. The influence of temperature and photoperiod in the phytotron on flowering parameters of Platycodon. Crowns were cooled for 12 weeks before planting. SD was of $8 \mathrm{~h}$ natural day light and LD of $8 \mathrm{~h}$ natural day light plus $8 \mathrm{~h}$ of incandescent light of $3.5 \mu \mathrm{mol} \cdot \mathrm{m}^{-2} \cdot \mathrm{s}^{-1}$.

\begin{tabular}{lccccc}
\hline \hline \multicolumn{2}{l}{ Growing conditions } \\
$\begin{array}{l}\text { Day/night } \\
\text { temp }\left({ }^{\circ} \mathrm{C}\right)\end{array}$ & $\begin{array}{c}\text { Day } \\
\text { length }\end{array}$ & $\begin{array}{c}\text { No. of days } \\
\text { to appearance of } \\
\text { flower buds }\end{array}$ & $\begin{array}{c}\text { No. } \\
\text { of days to } \\
\text { first flowering }\end{array}$ & $\begin{array}{c}\text { No. of } \\
\text { flowering stems } \\
\text { per plant }\end{array}$ & $\begin{array}{c}\text { Length of } \\
\text { flowering stems } \\
(\mathrm{cm})\end{array}$ \\
\hline $17 / 12$ & LD & $64 \mathrm{a}^{\mathrm{y}}$ & --- & $10.2 \mathrm{a}$ & --- \\
$22 / 17$ & SD & $70 \mathrm{a}$ & --- & $5.4 \mathrm{c}$ & $57.8 \mathrm{a}$ \\
$27 / 22$ & LD & $39 \mathrm{~b}$ & $57 \mathrm{a}$ & $6.0 \mathrm{c}$ & $44.0 \mathrm{~b}$ \\
$32 / 27$ & SD & $39 \mathrm{c}$ & $57 \mathrm{a}$ & $11.6 \mathrm{a}$ & $54.3 \mathrm{a}$ \\
& LD & $29 \mathrm{c}$ & $44 \mathrm{~b}$ & $6.5 \mathrm{c}$ & $49.0 \mathrm{ab}$ \\
& SD & $29 \mathrm{c}$ & $44 \mathrm{~b}$ & $3.5 \mathrm{~d}$ & $39.0 \mathrm{bc}$ \\
\hline
\end{tabular}

${ }^{2}$ Number of days from the transfer of plants to the phytotron rooms.

${ }^{y}$ Mean separation within columns by Duncan's multiple range test, $P \leq 0.05$. Means of five plants.

The balloon flower is a perennial herbaceous plant. Its initial growth is from seeds. Although the seedlings produce some flowers in the first growing season, flower production and quality are low. Commercial cut-flower production is obtained from the second flowering flush after precooling of crowns (Eversen and Beattie, 1986; Iversen and Weiler, 1994).

The effect of daylength and growing temperatures on flowering. Plants grown at the lowest temperature $\left(17 / 12{ }^{\circ} \mathrm{C}\right)$ did not flower after $92 \mathrm{~d}$ at the termination of the experiment (Table 3). Flower formation and development was accelerated with the rise in growing temperatures up to $27 / 22{ }^{\circ} \mathrm{C}$. However, flower production was significantly lower at the highest temperature $\left(32 / 27^{\circ} \mathrm{C}\right)$, and the stems were thin and short.

Photoperiod did not affect either the appearance of flower buds or the timing of flow- 
ering, indicating that Platycodon is a dayneutral plant, for both flower initiation and development as previously reported (Iversen and Weiler, 1994; Song et al., 1993). However, except in the highest temperature room, more flowers were produced when grown under LD. In addition, stems from LD treatments were longer than those from SD stems. This photoperiodic effect of LD is not related to higher light integral, since both photoperiodic treatments received the same $8 \mathrm{~h}$ of natural light and the $P A R$ from the added incandescent lighting in $\mathrm{LD}$ was negligible.

Comparison of winter growth in heated and unheated greenhouses. Flowering in the heated greenhouse began 2 weeks earlier in both growth flushes (Table 4). Flower production in the greenhouse heated to $16^{\circ} \mathrm{C}$ was somewhat higher than in the unheated greenhouse with ADT of $22.3^{\circ} \mathrm{C}$. However, flower quality, expressed in the length and weight of the flowering stems, was better in the unheated greenhouse, where night temperature ranged from 8 to $14{ }^{\circ} \mathrm{C}$ and ADT was $19.8^{\circ} \mathrm{C}$.

In a separate study, plants grown in a greenhouse heated to 12 to $14{ }^{\circ} \mathrm{C}$ resulted in better quality of flowering stems than those grown at a minimum of $16^{\circ} \mathrm{C}$ (data not shown). The quality of these plants was similar to those produced in unheated greenhouses. The minimum temperatures in the greenhouses used for commercial production of many cut flowers such as roses $\left(16\right.$ to $\left.18^{\circ} \mathrm{C}\right)$, were thus excessive for balloon flower. Heating, if applied, should not exceed 12 to $14{ }^{\circ} \mathrm{C}$.

Effect of cooling temperature, length of cooling and $\mathrm{GA}_{3}$ treatments on flowering. In their native habitat in northeast Asia, the plants bloom in the summer, the above-ground parts die in late autumn and only the below-ground crowns remain. After long freezing winter new growth begins in late spring. As previously reported by Iversen and Weiler (1994), cold treatment of crowns is essential to break the crown's dormancy and obtain flower production. The minimal cold treatment required to break dormancy and enable flower formation is 6 weeks, but we found that optimal results were obtained by cooling for 12 weeks in which maximum flower production and best flower quality, determined by stem length and number of flower buds per stem, were obtained (Table 5).

No difference was found in flowering

Table 4. Growth and flowering of Platycodon in the winter in a heated (minimum $16{ }^{\circ} \mathrm{C}$ ) and unheated greenhouse.

\begin{tabular}{|c|c|c|c|c|c|}
\hline \multirow{2}{*}{$\begin{array}{l}\text { Growing } \\
\text { conditions }\end{array}$} & \multicolumn{2}{|c|}{$\begin{array}{l}\text { Dates beginning } \\
\text { of flowering }\end{array}$} & \multirow{2}{*}{$\begin{array}{l}\text { No. of flowering } \\
\text { stems/plant/flush }\end{array}$} & \multirow{2}{*}{$\begin{array}{c}\text { Length of flowering } \\
\text { stems }(\mathrm{cm})\end{array}$} & \multirow{2}{*}{$\begin{array}{c}\text { Fresh wt of } \\
\text { flowering stems ( } g\end{array}$} \\
\hline & $1^{\text {st }}$ flush & $2^{\text {nd }}$ flush & & & \\
\hline Heated & Nov. 19 & Feb. 2 & $5.3 \mathrm{a}^{2}$ & $71.6 \mathrm{~b}$ & $15.8 \mathrm{~b}$ \\
\hline Nonheated & Dec. 3 & Feb. 18 & $4.2 \mathrm{~b}$ & $81.4 \mathrm{a}$ & $21.1 \mathrm{a}$ \\
\hline
\end{tabular}

${ }^{2}$ Mean separation within columns by Duncan's multiple range test, $P \leq 0.05$. Means of 20 plants ( 4 blocks $\times 5$ plants).

Table 5. Effect of cooling crowns of Platycodon at $2{ }^{\circ} \mathrm{C}$ for different lengths of time on flowering parameters. Crowns were uprooted at different times in the summer, transferred to a cold room, and planted in an unheated greenhouse on 1 Oct.

\begin{tabular}{lccc}
\hline $\begin{array}{l}\text { Length of } \\
\text { cold storage } \\
\text { (weeks) }\end{array}$ & $\begin{array}{c}\text { No. of } \\
\text { flowering stems } \\
\text { per plant }\end{array}$ & $\begin{array}{c}\text { Length of } \\
\text { flowering stems } \\
(\mathrm{cm})\end{array}$ & $\begin{array}{c}\text { No. of } \\
\text { flower buds } \\
\text { per stem }\end{array}$ \\
\hline 0 & $0.9 \mathrm{~d}^{\mathrm{y}}$ & $42.9 \mathrm{~d}$ & $2.5 \mathrm{e}$ \\
2 & $1.1 \mathrm{~d}$ & $39.3 \mathrm{~d}$ & $1.8 \mathrm{e}$ \\
4 & $1.4 \mathrm{~d}$ & $43.7 \mathrm{~d}$ & $2.1 \mathrm{e}$ \\
6 & $3.2 \mathrm{c}$ & $57.6 \mathrm{c}$ & $4.8 \mathrm{~cd}$ \\
8 & $3.6 \mathrm{c}$ & $65.7 \mathrm{~b}$ & $5.5 \mathrm{c}$ \\
10 & $4.8 \mathrm{~b}$ & $71.2 \mathrm{a}$ & $5.1 \mathrm{~cd}$ \\
12 & $5.4 \mathrm{a}$ & $74.1 \mathrm{a}$ & $9.9 \mathrm{a}$ \\
16 & $4.7 \mathrm{~b}$ & $73.2 \mathrm{a}$ & $7.4 \mathrm{~b}$ \\
\hline
\end{tabular}

${ }^{2}$ Open flowers and those showing color.

${ }^{y}$ Mean separation within columns by Duncan's multiple range test, $P \leq 0.05$. Means of 20 plants ( 4 blocks $\times 5$ plants). time and other flowering parameters between plants grown from crowns cooled at the three temperatures tested: $-2,2$, and $4{ }^{\circ} \mathrm{C}$ (data not shown).

$\mathrm{GA}_{3}$ treatments as crown dip or plant spraying did not affect flowering time and in most cases reduced flower production and quality, causing thin and weak stems (data not shown). This is contrary to the effect of $\mathrm{GA}_{3}$ in most other cold requiring plants in which $\mathrm{GA}_{3}$ can substitute for part of the cold requirement (Gianfagna, 1995).

In conclusion, the present study confirmed the results of earlier reports that Platycodon is a day-neutral plant, but we found that under LD more flowering stems were produced. Crown cooling for 12 weeks was optimal for obtaining best flower production and quality. The effect of cooling prevailed for two additional flushes. Optimal production and quality was obtained at growing under moderate temperatures of 12 to $27^{\circ} \mathrm{C}$. Too low and too high temperatures reduced production. These data will hopefully provide some additional information for the development of balloon flowers as a commercial cut flower crop.

\section{Literature Cited}

Armitage, A.M. 1989. Platycodon, p. 466-467. In: Herbaceous perennial plants. Varsity Press, Athens, Ga.

Bailey, L.H. 1935. Platycodon, p. 2710-2711. In: Standard cyclopedia of horticulture. Macmillan, New York.

Eversen, K. and D. Beattie. 1986. Using the balloon flower as a cut flower. HortScience 21:1061-1062.

Everett, T.H. 1981. Platycodon, p. 2717. In: The New York botanical garden encyclopedia of horticulture, Vol. 8. Garland Publ., New York.

Gianfagna, T. 1995. Natural and synthetic growth regulators and their use in horticultural and agronomic crops, p. 751-773. In: P.J. Davis (ed.). Plant hormones, physiology, biochemistry and molecular biology. Kluwer Academic, Dordrecht, The Netherlands.

Iversen, R.R. and T.C. Weiler. 1994. Strategies to force flowering of six herbaceous garden ornamentals. HortTechnology 4:61-65.

Park, B.H., N. Oliviera, and S. Pearson. 1998. Temperature affects growth and flowering of the balloon flower (Platycodon grandiflorus (Jacq.) A. DC. cv. Astra Blue. HortScience 33:233-236.

Shlomo, E., O. Ziv, and A.H. Halevy. 2000. Flower production of balloon flower (in Hebrew). Dapei Meida Perachim 9:70-74.

Song, C.Y., M.S. Roe, S.K. Chung, and R.H. Lawson. 1993. Effect of temperature and light on growth and flowering of potted plant production of Platycodon. J. Korea Soc. Hort. Sci. 34:446-453. 